\title{
Kidney cadmium levels and associations with urinary calcium and bone mineral density: a cross-sectional study in Sweden
}

\author{
Maria Wallin ${ }^{1 *}$, Gerd Sallsten ${ }^{1}$, Elisabeth Fabricius-Lagging ${ }^{2,3}$, Christian Öhrn ${ }^{1}$, Thomas Lundh ${ }^{4}$ and Lars Barregard ${ }^{1}$
}

\begin{abstract}
Background: Cadmium (Cd) can cause renal damage and osteoporosis after high-level exposure. Recently such effects, including increased urinary excretion of calcium, have been shown also at low-level exposure, as measured by $\mathrm{Cd}$ in blood or urine. However, associations with kidney $\mathrm{Cd}$ have not been examined. The aim of this study was to explore the relation between kidney $\mathrm{Cd}$ and urinary calcium excretion, or bone mineral density.
\end{abstract}

Methods: Cd was determined in kidney cortex biopsies from 109 living kidney donors. Serum was analyzed for ionized calcium, parathyroid hormone and vitamin D. Calcium was analyzed in overnight and 24-hour urine samples. Bone mineral density was measured in a subgroup of 67 donors. Associations between single variables were assessed by Spearman and Pearson correlation coefficients. Differences between independent groups were compared using Student's t-test. For related samples, paired t-test was applied. Associations between urinary calcium and kidney $\mathrm{Cd}$, ionized serum calcium, serum parathyroid hormone, inactive and active vitamin D and background variables were assessed using multiple linear regression and logistic regression.

Results: In spite of relatively low kidney Cd levels (median $13 \mu \mathrm{g} / \mathrm{g}$, range $1.5-55 \mu \mathrm{g} / \mathrm{g}$ ) kidney Cd and urinary calcium were positively associated, mainly caused by an association in women. Donors with kidney $\mathrm{Cd}$ above the median (subgroup mean $23 \mathrm{\mu g} / \mathrm{g}$ ) had significantly higher excretion of urinary calcium normalized for creatinine than those below the median (subgroup mean $7.3 \mu \mathrm{g} / \mathrm{g}$ ). In women, also the excretion of Ca per hour was higher in those with high kidney $\mathrm{Cd}$ ( 24 hour sample mean $0.21 \mathrm{vs.} 0.15 \mathrm{mmol} / \mathrm{h}$; overnight sample $0.16 \mathrm{vs} .0 .11 \mathrm{mmol} / \mathrm{h}$ ). There were negative associations between kidney $\mathrm{Cd}$ and bone mineral density, most of which, however, disappeared in multivariate analyses.

Conclusions: This study provides support for an association between kidney $\mathrm{Cd}$ levels and urinary calcium excretion in women, but not in men. The results strengthen the case for preventive measures against Cd pollution.

Keywords: Bone, Bone mineral density, Cadmium, Kidney, Urinary calcium, Kidney donor

\section{Background}

Cadmium (Cd) is a heavy metal, which occurs in the environment both naturally and as contamination from industries and agricultural fertilizers [1]. Cd is known to cause renal damage and bone demineralization and has also been classified as carcinogenic to humans [1]. The two major sources of $\mathrm{Cd}$ exposure in the general population are diet and tobacco smoking. Although women

\footnotetext{
* Correspondence: maria.wallin@amm.gu.se

'Department of Occupational and Environmental Medicine, Sahlgrenska University Hospital and Academy, University of Gothenburg, PO Box 414 SE-405 30, Gothenburg, Sweden

Full list of author information is available at the end of the article
}

have lower energy intake and Cd intake than men, they usually have higher $\mathrm{Cd}$ concentrations in blood, urine and kidney, since iron deficiency, which is more common among women, is known to increase gastrointestinal absorption [2-5]. Cd is thought to use the same transport pathways as essential metals such as zinc, calcium and iron in the intestine, and also calcium deficiency might increase $\mathrm{Cd}$ uptake [6,7]. After absorption, $\mathrm{Cd}$ is transported in the blood to the liver where it forms a complex with metallothionein (MT). In the kidneys, this Cd-MT complex is filtered in the glomeruli and thereafter reabsorbed in the renal tubules [2]. Cadmium 
is then accumulated in the kidney cortex, where it has a biological half-life of 10-30 years [1,2,5]. Cadmium is toxic especially to the proximal renal tubules, but may also cause impaired glomerular filtration and even renal failure [1]. An early effect of tubular damage is increased excretion of low molecular weight proteins [2], resulting from compromised tubular reabsorption. Urinary cadmium (U-Cd) is often used as a measure of long-term exposure to $\mathrm{Cd}$, as it is assumed to be proportional to kidney cadmium (K-Cd) and reflects the body burden, as long as the kidney function is intact $[1,2,5]$.

The effects of $\mathrm{Cd}$ on bone were first reported from Japan, where $\mathrm{Cd}$-polluted water was used on the rice fields and caused the Itai-Itai disease, a combination of osteomalacia, osteoporosis and kidney damage [2]. Recently, several studies have shown increased risk of osteoporosis and/or fractures even at low-level Cd exposure [8-13]. However, the mechanism for this effect of $\mathrm{Cd}$ on bone is not clear, despite several proposed theories, including interference with parathyroid hormone (PTH) or kidney enzymes involved in the activation of vitamin D $[14,15]$. Inactive vitamin $\mathrm{D}, 25(\mathrm{OH}) \mathrm{D} 3$, is hydroxylated in the kidney to its active form $1,25(\mathrm{OH})_{2} \mathrm{D} 3$, which increases the intestinal calcium absorption as well as the reabsorption of bone mineral matrix [14]. PTH has an important role in calcium homeostasis, as it stimulates vitamin $\mathrm{D}$ activation in the kidney, increases renal calcium reabsorption in the distal tubules and affects bone cells such as osteoblasts, osteoclasts and stromal cells [16].

Several studies have reported that occupational exposure to $\mathrm{Cd}$ increases the risk of kidney stones, which might be related to increased urinary calcium excretion [2]. Wu et al. reported a significant dose-response relationship between the prevalence of hypercalciuria and urinary $\mathrm{Cd}$ excretion in China [17]. Thus, one possible mechanism for the effects of $\mathrm{Cd}$ on bone is increased urinary calcium ( $\mathrm{U}-\mathrm{Ca}$ ) excretion, caused by $\mathrm{Cd}$-induced impairment of tubular reabsorption [2,18]. A study by Buchet et al. [19] showed that urinary calcium excretion, as well as other markers of renal tubular dysfunction, was significantly associated with $\mathrm{Cd}$ excretion in urine. However, recent studies indicate that increased calciuria might be caused by a direct effect of $\mathrm{Cd}$ on bone $[5,12,20]$.

The main purpose of this study was to explore the relation between kidney $\mathrm{Cd}$ and urinary calcium excretion in the general population, testing the hypothesis that long-term low-level exposure to $\mathrm{Cd}$ can increase calcium excretion in urine. In order to avoid possible artifacts by comparing two urinary biomarkers in the same sample [21], we studied the association between kidney $\mathrm{Cd}$ and urinary calcium. In addition, we investigated the relation between kidney $\mathrm{Cd}$ and bone mineral density. This is the first study to use kidney biopsy data for cadmium analyses from living donors, who we assume represent the healthy part of the general population.

\section{Methods \\ Kidney donors}

At the Department of Transplantation and Liver Surgery at Sahlgrenska University Hospital (Gothenburg, Sweden), 167 living kidney donors were invited to the present study, performed between January 1999 and June 2002 and between April 2004 and February 2005. Of these 167 kidney donors, 152 accepted to participate in the study (81\%). The median age of the 152 donors included in the study was 50 years (range 24-70). 87 of the included donors were women and 65 were men [22].

Before being accepted as kidney donors, the subjects had been examined with routine blood and urine tests, radiology and kidney function tests. These tests and examinations were made less than one year before the transplantation.

One or two days prior to transplantation, the donors were admitted to the hospital and underwent additional routine examinations as well as tests according to a study protocol. A physical examination was made and the donors were interviewed about their medical history. They also answered a questionnaire concerning occupation and smoking habits [22]. Blood tests were taken on the day of admission. A timed overnight urine sample was taken in the morning after admission and in most cases a separate timed 24-hour urine sample was also collected. Urine volume was measured in both samples. From April 2000 to December 2004, bone mineral density was measured in 95 of the donors.

A wedge biopsy was obtained from the kidney cortex during transplantation in $126 / 152$ donors (83\%) as part of the routine procedure at the Sahlgrenska University Hospital. The biopsy, which was taken from the lower pole of the kidney after revascularization, is normally used to determine the condition of the donor kidney and as a reference in case of later biopsies. Histopathological examination confirmed that the biopsy was taken from the kidney cortex. A part of the wedge biopsy was taken for analysis of heavy metal content. In 109 of the 126 donors (87\%, 60/87 women and 49/65 men), this part of the biopsy was transferred into pre-weighed acid-washed glass tubes and then frozen. The remaining 17 parts were too small or of inadequate quality to be used for chemical analysis.

All subjects gave informed consent to their participation in the study, which was approved by the Ethics Committee at the University of Gothenburg.

\section{Urine, blood and kidney biopsy analyses}

In the 109 donors with available kidney metal concentrations, 106 timed morning urine samples and 95 24-hour 
urine samples could be collected. The urine was analyzed for creatinine, using the Jaffé method (Roche Diagnostics) before June 2004 and thereafter with an enzymatic method (photometry, Modular P, Roche and CREAplus R1, R2, Roche Diagnostics, Mannheim, Germany), and calcium, using photometry (Modular, Roche and Ca R1, R2, Roche Diagnostics, Mannheim, Germany). Imprecision was 3-5\% (CV, coefficient of variation). In the timed overnight sample, urinary calcium was missing in one sample. In 24 hour urine, urinary calcium was missing for two samples, and results were excluded for three samples as the sample time was too short ( $\leq 15$ hours). The results for 24-hour urine samples with volumes $<700 \mathrm{ml}(\mathrm{n}=3)$ and $>5000 \mathrm{ml}(\mathrm{n}=1)$ were considered false or not representative and were excluded from the statistical analyses. Statistical analyses were made on the remaining 86 24-hour urine samples. Serum samples were analyzed for ionized $\mathrm{Ca}$, parathyroid hormone $(\mathrm{PTH})$ and inactive and active vitamin D3 (calcidiol or $25(\mathrm{OH}) \mathrm{D} 3$ and calcitriol or $1,25(\mathrm{OH})_{2} \mathrm{D} 3$ ). Ionized S-Ca (pH adjusted) was measured by ion-selective electrometry (ABL 805/825, Radiometer Copenhagen). PTH was measured by an immunoradiometric assay (IRMA, manual method) before November 2001 and thereafter by an immunochemical luminometric assay (Nichols Advantage Specialty System). Serum levels of $25(\mathrm{OH}) \mathrm{D} 3$ and $1,25(\mathrm{OH})_{2} \mathrm{D} 3$ were examined using a radioimmunochemical method (RIA, manual method, Perking Elmer Wizard 1470 gamma counter). All standard serum and urine analyses were performed by an ISO accredited laboratory (Department of Clinical Chemistry, Sahlgrenska University Hospital, Gothenburg). Cd concentrations in the kidney biopsies were determined by inductively coupled plasma-mass spectrometry (ICP-MS; Thermo X7, Thermo Elemental, Winsford, UK) [23], for details, see Barregard et al. [22].

\section{Assessment of BMD}

BMD (bone mineral density; $\mathrm{g} / \mathrm{cm}^{2}$ ) of the total body, lumbar spine, femoral neck, trochanter, ward and forearm was measured in a subgroup (67 of the 109 donors with data available for kidney $\mathrm{Cd}$ ) using dual-energy X-ray absorptiometry (Lunar DPX-L, GE Lunar Corp.).

\section{Statistical analyses}

Associations between single variables were assessed by Spearman and Pearson correlation coefficients $\left(r_{s}\right.$ and $\left.r_{p}\right)$. Differences between groups were compared using Student's $\mathrm{t}$-test for independent groups and paired $\mathrm{t}$-test for related samples. Associations between urinary calcium and kidney $\mathrm{Cd}$, ionized serum calcium, serum PTH, inactive and active vitamin $\mathrm{D}$ and background variables were assessed using multiple linear regression and logistic regression. We chose to calculate urinary calcium excretion both per hour and normalized for creatinine. The reason for this is that we would like to compare urinary Ca levels in our study with other published studies which have used U-Ca normalized for creatinine (as samples were not timed). We also wanted to correct for the fact that males have higher lean body mass than females, and therefore excrete more Ca per hour. In order to detect a possible threshold effect of kidney $\mathrm{Cd}$, we also calculated associations with urinary calcium after dividing the donors in two groups, with "high" or "low" kidney cadmium (K-Cd $>$ or $\leq$ the median).

Since bone resorption increases after menopause in women, a menopause variable was included in the regression analyses, assuming menopause for women aged $>51$ years, which is the median age of natural menopause [24]. Statistical evaluations were performed using SAS (version 9.2).

\section{Results}

A summary of $\mathrm{Cd}$ concentrations in the kidney cortex biopsies from the 109 donors and some biomarkers related to calcium metabolism are shown in Table 1. The $\mathrm{Cd}$ concentrations were generally relatively low (mean 15.0, median $12.9 \mu \mathrm{g} / \mathrm{g}$ wet weight). Women had significantly higher kidney $\mathrm{Cd}$ than men (mean 17.1, median $14.7 \mu \mathrm{g} / \mathrm{g}$ wet weight for women and mean 12.5 , median $10.9 \mu \mathrm{g} / \mathrm{g}$ wet weight for men, $\mathrm{p}=0.01$ ).

Table 1 also shows serum levels of ionized $\mathrm{Ca}$, parathyroid hormone, $25(\mathrm{OH}) \mathrm{D} 3$, and $1,25(\mathrm{OH})_{2} \mathrm{D} 3$, together with the urinary calcium excretion in 24-hour samples and timed overnight samples. The excretion of $\mathrm{U}$-Ca per hour was significantly higher in the 24 hoursamples than in the timed morning sample $(\mathrm{p}<0.001)$. This difference was found also after normalizing for creatinine $(\mathrm{p}<0.001)$. There was a positive correlation between the excretion of $\mathrm{U}-\mathrm{Ca}(\mathrm{mmol} / \mathrm{h})$ and urinary creatinine $(\mathrm{mmol} / \mathrm{h})\left(\mathrm{r}_{\mathrm{p}}=0.45, \mathrm{p}<0.001\right.$ for the 24-hour sample and $r_{p}=0.35, p<0.001$ for the timed overnight sample). In overnight urine, there was also a significant positive correlation between diuresis (urinary flow rate $\mathrm{mL} / \mathrm{h})$ and $\mathrm{U}-\mathrm{Ca}\left(\mathrm{r}_{\mathrm{p}}=0.30, \mathrm{p}=0.002\right)$ and creatinine $\left(r_{p}=0.28, p=0.004\right)$ excretion rates. Men excreted significantly more U-Ca per hour than women, both in the 24-hour sample $(\mathrm{p}<0.001)$ and in the timed overnight urine sample $(p=0.005)$. After normalizing for creatinine, there was instead a trend for women to excrete more UCa than men (Table 1).

U-Ca excretion (excretion rates per hour and levels normalized for creatinine) was positively correlated with ionized S-Ca (Table 2). U-Ca normalized for creatinine was positively correlated with age and menopause (defined as age $>51$ years in women). Weight was positively associated with U-Ca excretion per hour, but negatively correlated with U-Ca normalized for creatinine (Table 2). 
Table 1 Kidney cadmium concentrations (K-Cd), calcium excretion (U-Ca) and levels of biomarkers related to calcium metabolism in healthy kidney donors

\begin{tabular}{|c|c|c|c|c|c|c|c|c|c|}
\hline & \multicolumn{3}{|c|}{ All } & \multicolumn{3}{|c|}{ Men } & \multicolumn{3}{|c|}{ Women } \\
\hline & $\mathrm{N}$ & Median & Range & $\mathrm{N}$ & Median & Range & $\mathrm{N}$ & Median & Range \\
\hline $\mathrm{K}-\mathrm{Cd}(\mu \mathrm{g} / \mathrm{g}$ wet weight) & 109 & 12.9 & $1.5-55.4$ & 49 & 10.9 & $1.6-31.7$ & 60 & 14.7 & 1.5-55.4 \\
\hline Age (years) & 109 & 51 & $24-70$ & 49 & 52 & $32-70$ & 60 & 50 & $24-64$ \\
\hline Smokers: never/ever & $41 / 68$ & & & 19/30 & & & $22 / 38$ & & \\
\hline \multicolumn{10}{|l|}{ 24-hour sample } \\
\hline$\underline{\mathrm{U}-\mathrm{Ca}(\mathrm{mmol} / \mathrm{l})}$ & 86 & 3.0 & $0.74-7.1$ & 39 & 3.5 & $0.96-7.1$ & 47 & 2.4 & $0.74-5.3$ \\
\hline U-Ca (mmol/h) & 86 & 0.21 & $0.05-0.41$ & 39 & 0.25 & $0.08-0.41$ & 47 & 0.19 & $0.05-0.34$ \\
\hline $\mathrm{U}-\mathrm{Ca}(\mathrm{mmol} / 24 \mathrm{~h})$ & 86 & 5.1 & $1.3-9.8$ & 39 & 5.9 & $1.8-9.8$ & 47 & 4.5 & $1.3-8.1$ \\
\hline U-Ca (mmol/mmol creatinine) & 86 & 0.43 & $0.14-1.4$ & 39 & 0.42 & 0.14-0.79 & 47 & 0.50 & $0.17-1.4$ \\
\hline \multicolumn{10}{|l|}{ Overnight sample } \\
\hline U-Ca (mmol/l) & 105 & 3.4 & $0.64-15$ & 47 & 4.2 & $0.67-11$ & 58 & 3.1 & $0.64-15$ \\
\hline U-Ca (mmol/h) & 105 & 0.15 & 0.03-0.4 & 47 & 0.18 & $0.04-0.41$ & 58 & 0.13 & $0.03-0.30$ \\
\hline U-Ca (mmol/mmol creatinine) & 105 & 0.31 & 0.06-1.1 & 47 & 0.31 & $0.07-0.67$ & 58 & 0.32 & 0.06-1.06 \\
\hline \multicolumn{10}{|l|}{ Serum } \\
\hline 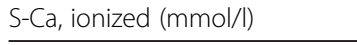 & 107 & 1.2 & $1.0-1.4$ & 48 & 1.2 & $1.2-1.3$ & 59 & 1.2 & $1.0-1.4$ \\
\hline $\mathrm{S}-25(\mathrm{OH}) \mathrm{D} 3(\mathrm{ng} / \mathrm{ml})$ & 98 & 25.5 & $8.1-48.9$ & 45 & 24.1 & $11.5-48.9$ & 53 & 26.3 & $8.1-46.1$ \\
\hline $\mathrm{S}-1.25(\mathrm{OH})_{2} \mathrm{D} 3(\mathrm{pg} / \mathrm{ml})$ & 98 & 33.8 & 13.7-97.1 & 45 & 33.0 & 18.6-97.1 & 53 & 34.9 & 13.7-70.8 \\
\hline$\underline{\text { S-PTH }(n g / l)}$ & 106 & 38.4 & 14.8-398 & 48 & 43.6 & 20.6-398 & 58 & 36.7 & $14.8-91.6$ \\
\hline
\end{tabular}

\section{Association between kidney $\mathrm{Cd}$ and urinary Ca excretion} There was a significant positive correlation between continuous kidney $\mathrm{Cd}$ and urinary calcium normalized for creatinine (Figure 1), both in the 24-hour sample $\left(\mathrm{r}_{\mathrm{s}}=\right.$ $\left.0.32, p=0.003, r_{p}=0.27, p=0.01\right)$ and in the timed overnight sample $\left(r_{s}=0.27, p=0.005, r_{p}=0.27, p=0.006\right)$, while there was no such association for Ca excretion per hour (Table 2). Likewise, in women kidney cadmium (as a continuous variable) correlated significantly to urinary calcium normalized for creatinine (24-hour sample $\mathrm{p}=0.02$; overnight sample $\mathrm{p}=0.004$ ) and urinary calcium excretion per hour $(p=0.049$ and $p=0.004)$ (Table 2). In men, there were no such significant associations.

We also calculated associations between categorical $\mathrm{K}-\mathrm{Cd}$ and $\mathrm{U}-\mathrm{Ca}$, dividing the donors in those above ("high $\mathrm{K}-\mathrm{Cd}$ ") and equal to or below ("low $\mathrm{K}-\mathrm{Cd}$ ") the median kidney Cd (12.9 $\mu \mathrm{g} / \mathrm{g}$ ) (mean high $\mathrm{K}-\mathrm{Cd} 22.9$, low K-Cd $7.3 \mu \mathrm{g} / \mathrm{g})$. Donors with high kidney $\mathrm{Cd}$ had higher excretion of U-Ca normalized for creatinine than those with low kidney Cd (24 hour sample mean 0.53 vs. $0.39 \mathrm{mmol} \mathrm{Ca} /$ mmol creatinine, $\mathrm{p}<0.001$ (Additional file 1: Figure S2); overnight sample 0.40 vs. $0.31 \mathrm{mmol} \mathrm{Ca} / \mathrm{mmol}$ creatinine, $\mathrm{p}=0.02$ ). This was mainly caused by a difference in women $(\mathrm{p}=0.001$ and $\mathrm{p}=0.02)$, while there was no significant difference in men. In women, also the excretion of $\mathrm{Ca}$ per hour was higher in those with high kidney Cd (24 hour sample mean 0.21 vs. $0.15 \mathrm{mmol} / \mathrm{h}, \mathrm{p}=0.006$; overnight sample 0.16 vs. $0.11 \mathrm{mmol} / \mathrm{h}, \mathrm{p}=0.01)$. When stratifying for smoking (ever/never-smokers), those with high kidney
Cd had significantly higher 24-hour urinary calcium normalized for creatinine both in never-smokers $(p=0.009)$, and in ever-smokers $(\mathrm{p}=0.03)$.

In multiple linear regression models, including categorical kidney Cd (high/low), age, sex, weight, menopause, ionized serum calcium, urinary flow rate, and vitamin D (25(OH)D3), urinary calcium excretion in the 24-hour sample was significantly associated with high kidney Cd (20\% higher U-Ca mmol/h, p $=0.04$, and 32\% higher U-Ca normalized for creatinine, $\mathrm{p}=0.002$ ) (Table 3). There was, however, no such impact of kidney $\mathrm{Cd}$ in the overnight urine sample. The regression model was constructed after backward elimination and smoking, serum PTH and $1,25(\mathrm{OH})_{2} \mathrm{D} 3$ were excluded from the final model as these variables were not significantly associated with urinary calcium excretion. We repeated the multiple linear regression analysis for women and men separately. In women, again, high kidney $\mathrm{Cd}$ had a significant impact on $\mathrm{U}-\mathrm{Ca}$ in the 24-hour urine sample ( $40 \%$ higher $\mathrm{U}-\mathrm{Ca} \mathrm{mmol} / \mathrm{h}, \mathrm{p}=0.01$, and $47 \%$ higher $\mathrm{U}-\mathrm{Ca}$ normalized for creatinine, $\mathrm{p}=0.003)$. In men, no effect of kidney $\mathrm{Cd}$ was found. When kidney $\mathrm{Cd}$ was treated as a continuous variable, the effect of kidney $\mathrm{Cd}$ was not statistically significant ( $\mathrm{p}=0.08$ for U-Ca normalized for creatinine in 24-hour urine) (Additional file 2: Table S1 and S2).

We also tested the impact of high kidney $\mathrm{Cd}$ on the odds of having high calcium excretion in the 24-hour sample, defined as the upper quartile of U-Ca $(>0.56 \mathrm{mmol} / \mathrm{mmol}$ creatinine). In a stepwise $(\mathrm{p}=0.1$ for inclusion in the 
Table 2 Correlations between parameters (Pearson's correlation coefficients)

\begin{tabular}{|c|c|c|c|c|c|c|c|c|c|c|c|c|c|}
\hline & $\begin{array}{l}\text { K-Cd } \\
(\mu \mathrm{g} / \mathrm{g} \\
w w)\end{array}$ & Age & Sex & Weight & Menopause & $\begin{array}{l}\text { S-Ca, } \\
\text { ionized } \\
(\mathrm{mmol} / \mathrm{l})\end{array}$ & $\begin{array}{l}24-\mathrm{h} \\
\text { urinary } \\
\text { flow rate } \\
(\mathrm{ml} / \mathrm{h})\end{array}$ & $\begin{array}{l}\text { Overnight urinary } \\
\text { flow rate }(\mathrm{ml} / \mathrm{h})\end{array}$ & $\begin{array}{l}\text { S-25(OH)D3 } \\
(\mathrm{ng} / \mathrm{ml})\end{array}$ & $\begin{array}{l}\text { 24-h U-Ca } \\
(\mathrm{mmol} / \mathrm{h})\end{array}$ & $\begin{array}{l}\text { 24-h U-Ca (mmol/ } \\
\text { mmol creatinine) }\end{array}$ & $\begin{array}{l}\mathrm{ON} \mathrm{U}-\mathrm{Ca} \\
(\mathrm{mmol} / \mathrm{h})\end{array}$ & $\begin{array}{l}\text { ON U-Ca (mmol/ } \\
\text { mmol creatinine) }\end{array}$ \\
\hline $\mathrm{K}-\mathrm{Cd}, \mu \mathrm{g} / \mathrm{g} w \mathrm{w}$ & & $0.28 * *$ & $0.24^{*}$ & $-0.27^{* *}$ & $0.33^{* * *}$ & 0.06 & -0.09 & 0.09 & 0.14 & -0.06 & $0.27^{*}$ & 0.05 & $0.27^{* *}$ \\
\hline Age & $0.33^{* *}$ & & -0.10 & -0.009 & $0.44^{* *}$ & $-0.22^{*}$ & $-0.29 * *$ & 0.08 & 0.13 & 0.006 & $0.25^{*}$ & 0.14 & $0.23 *$ \\
\hline Sex & & & & $-0.57^{* *}$ & $0.49 * *$ & 0.06 & 0.07 & -0.12 & 0.09 & $-0.41^{* *}$ & 0.16 & $-0.27^{* *}$ & 0.15 \\
\hline Weight & -0.10 & 0.04 & & & $-0.32^{* *}$ & 0.15 & -0.09 & 0.06 & $-0.22^{*}$ & $0.23^{*}$ & $-0.30^{* *}$ & 0.17 & $-0.25^{*}$ \\
\hline Menopause & $0.31^{*}$ & $0.77^{* *}$ & & -0.08 & & -0.13 & -0.13 & -0.03 & 0.08 & -0.14 & $0.29 * *$ & 0.05 & $0.34^{* *}$ \\
\hline $\begin{array}{l}\text { S-Ca, ionized, } \\
\mathrm{mmol} / / \mathrm{l}\end{array}$ & 0.17 & -0.15 & & 0.21 & -0.22 & & 0.05 & 0.12 & -0.06 & 0.21 & $0.30^{* *}$ & $0.22^{*}$ & $0.26^{* *}$ \\
\hline $\begin{array}{l}\text { 24-h urinary flow } \\
\text { rate, } \mathrm{ml} / \mathrm{h}\end{array}$ & -0.02 & -0.25 & & -0.01 & -0.23 & 0.06 & & $0.43^{* *}$ & 0.13 & -0.01 & -0.06 & -0.06 & -0.07 \\
\hline $\begin{array}{l}\text { Overnight urinary } \\
\text { flow rate, } \mathrm{ml} / \mathrm{h}\end{array}$ & 0.25 & -0.04 & & -0.11 & 0.05 & 0.15 & $0.52^{* *}$ & & 0.02 & 0.005 & 0.06 & $0.30 * *$ & 0.16 \\
\hline $\begin{array}{l}\mathrm{S}-25(\mathrm{OH}) \mathrm{D} 3, \mathrm{ng} / \\
\mathrm{ml}\end{array}$ & 0.07 & 0.05 & & -0.08 & 0.05 & -0.003 & 0.19 & 0.08 & & -0.22 & -0.11 & -0.01 & 0.08 \\
\hline $\begin{array}{l}\text { 24-h U-Ca, mmol/ } \\
\text { h }\end{array}$ & $0.29^{*}$ & 0.19 & & -0.10 & 0.17 & 0.24 & 0.11 & 0.08 & -0.07 & & $0.62^{* *}$ & $0.63^{* *}$ & $0.46^{* *}$ \\
\hline $\begin{array}{l}\text { 24-h U-Ca, mmol/ } \\
\text { mmol creatinine }\end{array}$ & $0.35^{*}$ & $0.36^{*}$ & & -0.26 & 0.28 & $0.31^{*}$ & -0.03 & 0.14 & -0.07 & $0.82^{* *}$ & & $0.47^{* *}$ & $0.72^{* *}$ \\
\hline $\begin{array}{l}\text { ON U-Ca, mmol/ } \\
\text { h }\end{array}$ & $0.37^{* *}$ & 0.25 & & -0.19 & $0.33^{*}$ & 0.19 & 0.04 & $0.31^{*}$ & 0.25 & $0.56^{* *}$ & $0.57^{* *}$ & & $0.77^{* *}$ \\
\hline $\begin{array}{l}\text { ON U-Ca, mmol/ } \\
\text { mmol creatinine }\end{array}$ & $0.37^{* *}$ & $0.29^{*}$ & & $-0.27^{*}$ & $0.36^{* *}$ & 0.25 & -0.03 & 0.21 & 0.22 & $0.57^{* *}$ & $0.70^{* *}$ & $0.91^{* *}$ & \\
\hline
\end{tabular}

Upper right triangular part of the table: all (bold). Lower left: women.

$\mathrm{ON}=$ overnight sample. Menopause assumed for women aged $>51$ years. ${ }^{*} \mathrm{p}<0.05,{ }^{* *} \mathrm{p}<0.01$. 


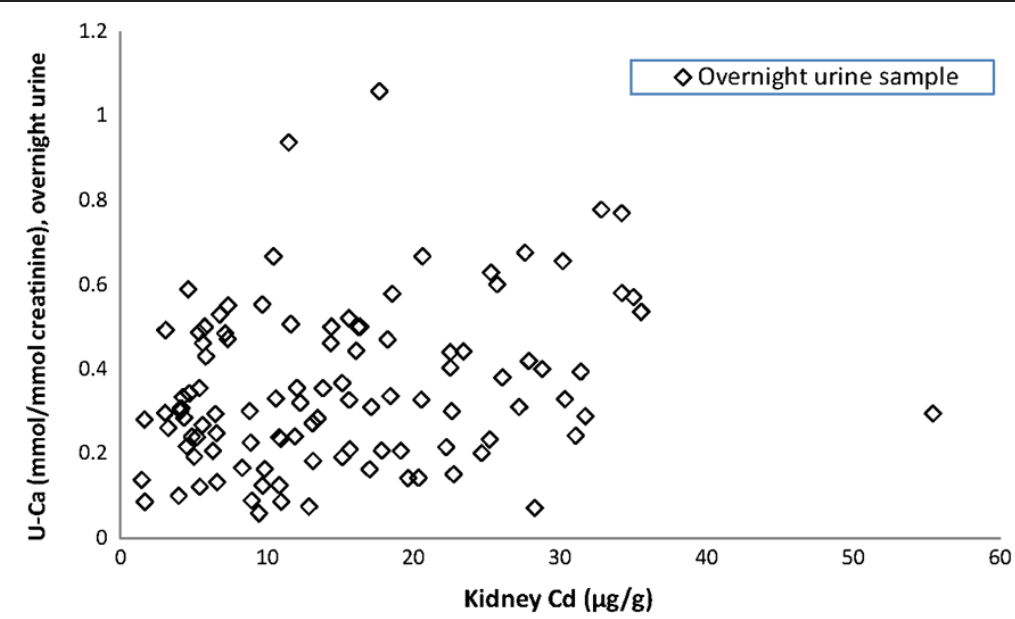

Figure 1 Excretion of urinary calcium (U-Ca) in overnight urine $(\mathrm{mmol} \mathrm{Ca} / \mathrm{mmol}$ creatinine) as a function of kidney cadmium (kidney $\mathrm{Cd}, \mu \mathrm{g} / \mathrm{g}$ wet weight) in living kidney donors $(\mathrm{N}=105)$.

model) logistic regression model high kidney $\mathrm{Cd}$ increased the odds of having high U-Ca normalized for creatinine (OR 5.5, 95\% CI 1.6-19). The only other variable included in the final model was body weight (Additional file 2: Table S3). When stratifying for sex, the risk estimate was higher for women; OR 8.9 (95\% CI 1.6-49) for having high U-Ca normalized for creatinine. For men, the OR was 2.4 (95\% CI 0.4-16) but not statistically significant. There was no significant effect of high kidney cadmium on the odds of having high calcium excretion per hour (Additional file 2: Table S3).

In multivariate analyses with either serum ionized $\mathrm{Ca}$, parathyroid hormone, or inactive or active vitamin D3 as the dependent variable, we found no significant associations with kidney $\mathrm{Cd}$ (dichotomized or continuous). In women, there was however a tendency towards an association between dichotomized kidney $\mathrm{Cd}$ and ionized $\mathrm{S}-\mathrm{Ca}(\mathrm{p}=0.053)$.
Association between kidney $\mathrm{Cd}$ and bone mineral density High kidney Cd (above median) was negatively associated with BMD for total body, spine, femur and forearm. However, in multiple linear regression analyses, including possible confounders and effect modifiers in the model (age, sex, body weight, menopause, smoking and vitamin D), we found no significant associations between kidney Cd and BMD for any location (Additional file 2: Table S4). For total body and femur, weight was the only factor significantly associated to BMD in the model. Forearm BMD was associated with sex as well (lower in women). Smoking was the only factor in the model significantly associated with BMD of the spine.

In group comparison, smokers with high kidney $\mathrm{Cd}$ had lower BMD for total body, spine, femur and forearm than those with low kidney $\mathrm{Cd}$, but the differences were not statistically significant ( $p=0.06$ for total body, Additional file 3: Figure S3), except for BMD of the femoral trochanter

Table 3 Multiple linear regression analysis with $\mathrm{U}-\mathrm{Ca}$ as the dependent variable

\begin{tabular}{|c|c|c|c|c|}
\hline & 24-h U-Ca (mmol/h) & 24-h U-Ca (mmol/mmol creatinine) & ON U-Ca (mmol/h) & ON U-Ca ( $\mathrm{mmol} / \mathrm{mmol}$ creatinine) \\
\hline$\overline{R^{2}}$ & 0.34 & 0.52 & 0.27 & 0.31 \\
\hline Intercept & -0.39 & -2.1 & -0.78 & -2.1 \\
\hline \multicolumn{5}{|l|}{ Regression coefficients } \\
\hline Categorical K-Cd (high/low) & $0.04^{*}$ & $0.12^{* *}$ & -0.002 & 0.01 \\
\hline Age & -0.001 & 0.003 & 0.0004 & 0.003 \\
\hline Sex & $-0.09^{* *}$ & -0.09 & $-0.05^{*}$ & -0.04 \\
\hline Weight & -0.0004 & $-0.006^{* *}$ & 0.0005 & $-0.004^{*}$ \\
\hline Menopause & 0.04 & 0.09 & 0.04 & $0.13^{*}$ \\
\hline S-Ca, ionized, mmol/l & $0.57^{*}$ & $2.4^{* *}$ & $0.69^{* *}$ & $2.05^{* *}$ \\
\hline 24-h urinary flow rate, $\mathrm{ml} / \mathrm{h}$ & 0.0007 & 0.001 & & \\
\hline ON urinary flow rate, $\mathrm{ml} / \mathrm{h}$ & & & $0.0007^{*}$ & 0.0009 \\
\hline $\mathrm{S}-25(\mathrm{OH}) \mathrm{D} 3, \mathrm{ng} / \mathrm{ml}$ & $-0.003^{*}$ & $-0.006^{* *}$ & 0.0002 & 0.0003 \\
\hline
\end{tabular}

$\mathrm{ON}=$ overnight sample. Menopause assumed for women aged $>51$ years (coded 1 if present, otherwise 0 ). $\mathrm{N}=76$ observations used. ${ }^{*} \mathrm{p}<0.05,{ }^{* *} \mathrm{p}<0.01$. 
$(p=0.049)$. In those aged $>51$ years, BMD for total body, the femoral trochanter and part of the forearm was significantly lower in the group with high kidney $\mathrm{Cd}(\mathrm{p}<0.05$, Additional file 3: Figure S3). The difference was not significant for the younger group.

When the multivariate analyses were repeated and stratified for sex or age, the only statistically significant association between kidney $\mathrm{Cd}$ (high/low) and BMD was in the forearm in those aged $\leq 51$ years $(p=0.03)$. An analysis stratified for smoking showed no significant associations between BMD and kidney Cd.

There were significant negative correlations between BMD and urinary calcium normalized for creatinine for most sites. However, in a multiple regression model including age, sex, body weight, menopause, smoking and vitamin $\mathrm{D}$, these associations were no longer significant.

\section{Discussion}

This study is the first to report significant positive associations between kidney $\mathrm{Cd}$ levels in biopsies from living donors and urinary calcium excretion. We observed that donors with high kidney $\mathrm{Cd}$ (above the median) had significantly higher U-Ca excretion normalized for creatinine than those with low kidney $\mathrm{Cd}$, mainly due to a significant difference in women but not men. We also found a significant positive association between $\mathrm{U}-\mathrm{Ca}$ excretion in the 24-hour sample and kidney $\mathrm{Cd}$ in a multiple linear regression model, including age, sex, weight, menopause, ionized serum calcium, urinary flow rate and vitamin $\mathrm{D}(25(\mathrm{OH}) \mathrm{D} 3)$. We believe that the association was stronger in 24-hour urine because that sample was collected during a longer time than the overnight sample, and should therefore give a more reliable measure of the mean urinary calcium concentration.

Men excreted significantly more U-Ca per hour than women, in accordance with previous studies [25]. However, after normalizing for creatinine $(\mathrm{Ca} / \mathrm{creatinine}$ ratio), there was a trend for women to excrete more calcium than men. The tendency towards stronger associations between kidney $\mathrm{Cd}$ and $\mathrm{U}-\mathrm{Ca}$ when using dichotomized instead of continuous kidney $\mathrm{Cd}$ could indicate a threshold effect, very low kidney cadmium levels not affecting U-Ca.

Cadmium is known to affect both kidney function and the skeleton, as was first described as the Itai-Itai disease in Japan [2]. Later studies have confirmed an increased risk for osteoporosis and/or fractures after $\mathrm{Cd}$ exposure [8-13]. We focused on the relationship between kidney $\mathrm{Cd}$ and urinary calcium excretion, but we also measured BMD in part of the study population. The effect of $\mathrm{Cd}$ on calcium metabolism is interesting as urinary calcium is a marker of tubular function, but also because calcium is the most important mineral in the bone tissue. Some previous studies have shown a positive association between urinary $\mathrm{Cd}$, as a marker of $\mathrm{Cd}$ body burden, and calcium excretion $[17,19]$. However, urinary $\mathrm{Cd}$ is not an ideal indicator of the body burden because $\mathrm{Cd}$ excretion may increase when kidney function is impaired, and $\mathrm{Cd}$ may be co-excreted with urinary proteins [21,26,27]. One of the strengths with this study is the use of kidney $\mathrm{Cd}$, which eliminates the risk of a non-causal association due to diuresis or co-excretion of $\mathrm{Cd}$ and protein.

The effect of kidney $\mathrm{Cd}$ on urinary calcium excretion was mainly seen in women. This is supported by a study of residents in Thailand with elevated urinary $\mathrm{Cd}$, where the fractional excretion of calcium increased with rising cadmium exposure (urinary $\mathrm{Cd}$ ) especially in women [28]. In that study, there was also a positive correlation between fractional calcium excretion and the excretion of bone resorption markers, and the levels of those markers were significantly higher in women. This could indicate that women are at higher risk for bone effects resulting from cadmium exposure than men.

The mechanism behind the increased urinary calcium excretion in donors with high kidney $\mathrm{Cd}$ in this study is not clear, but it could be an effect of early renal tubular dysfunction [17] or a direct effect on bone, possibly by increased bone resorption $[2,5,12,14,15,20]$. A third possibility is that calcium deficiency, following calcium loss in the urine, has led to an increased expression of essential metal transporters in the intestine, thereby also increasing the absorption of cadmium [6,7]. An increased calcium excretion can be both the cause of, and an effect of, increased bone resorption, which can result in low BMD (osteopenia or osteoporosis) and increased risk of fractures $[10,11,13]$.

In the present study, we found significant negative correlations between kidney $\mathrm{Cd}$ and BMD in the univariate analyses, but no significant associations in the multiple regression analyses, where body weight was the predominant factor and positively associated to BMD. Other possible confounders or effect modifiers included in the model were age, sex, menopause, smoking and vitamin D. The absence of significant associations could indicate that the increased $\mathrm{Ca}$ excretion is not associated with low BMD at these low Cd levels. However, with BMD measured in only 67 of the 109 donors with data on kidney $\mathrm{Cd}$ levels, our small group size provides limited power to find an association between kidney $\mathrm{Cd}$ and BMD. In addition, most of our subjects may have been too young to have an effect of $\mathrm{Cd}$ on BMD (median age 51 years).

Increasing age, female gender, estrogen deficiency, e.g. at menopause, low BMI and weight, osteoporosis in the family history, smoking and previous fractures are known risk factors for low BMD [29]. There is also a positive association between physical activity and bone mass. We had no information about menopausal age, osteoporosis in the family or level of physical activity, 
which is a limitation of the study. However, menopause was assumed for women aged $>51$ years, which is the median age for menopause [24]. We also had no information about dietary calcium intake, which may contribute to variability in calcium levels. Vitamin D is usually affected by season, which was confirmed in this study (data not shown). These sources of variability in covariates could lead to some misclassification, but such misclassification should be non-differential.

The biopsies in the study were taken from living kidney donors. In other circumstances it would not be ethical to take kidney biopsies from healthy people, but at this transplantation center a "baseline" biopsy is normally taken from the donated kidney, as part of the routine at transplantation. Thus the study group does not include subjects with diabetes or other serious systemic diseases. However, we consider them representative for the healthy part of the general population.

\section{Conclusions}

In the present study, we found significant positive associations between urinary calcium excretion and kidney cortex $\mathrm{Cd}$ in healthy subjects, mainly women, in spite of rather low kidney $\mathrm{Cd}$ (median $12.9 \mu \mathrm{g} / \mathrm{g}$ ). This relation between kidney $\mathrm{Cd}$ and urinary calcium provides some support for the results from other studies, which have shown an effect on calcium excretion and kidney function at low levels of urinary $\mathrm{Cd}[2,19]$, especially a study from Thailand showing increased fractional excretion of calcium with rising cadmium exposure particularly in women [28]. The results from our study somewhat strengthen the case for preventive measures against $\mathrm{Cd}$ pollution, although more research is needed to explain the mechanisms of the effects of $\mathrm{Cd}$ on bone and calcium metabolism.

\section{Additional files}

Additional file 1: Figure S2. Mean excretion of urinary calcium (U-Ca) in 24-hour urine ( $\mathrm{mmol} \mathrm{Ca} / \mathrm{mmol}$ creatinine) at kidney cadmium below or above the median (low/high kidney $\mathrm{Cd}$ ) in living kidney donors $(\mathrm{N}=86)$

Additional file 2: Table S1. Multiple linear regression analysis with $\mathrm{U}-\mathrm{Ca}$ as the dependent variable. Table S2. Multiple linear regression analysis with U-Ca as the dependent variable (women). Table S3. Multiple logistic regression analysis with high U-Ca (upper quartile) as the dependent variable. Table S4. Multiple linear regression analysis with $\mathrm{BMD}$ as the dependent variable.

Additional file 3: Figure S3. Mean bone mineral density (BMD), total body, at kidney cadmium below or above the median (low/high kidney Cd) in living kidney donors stratified for smoking (ever/never) and age ( $\leq 51$ or $>51$ years).

\section{Abbreviations}

25(OH)D3: 25-hydroxyvitamin D or calcidiol; 1,25(OH) 2 D3: 1,25dihydroxyvitamin D or calcitriol; BMD: Bone mineral density; Ca: Calcium; Cd: Cadmium; EFSA: European Food Safety Authority; K-Cd: Kidney cadmium; MT: Metallothionein; PTH: Parathyroid hormone; U-Ca: Urinary calcium; ww: Wet weight
Competing interests

All authors state that they have no conflicts of interest.

\section{Authors' contributions}

Study design: GS, EFL, LB. Study conduct: GS, EFL, TL, LB. Data collection: MW, GS, EFL, TL, LB. Data analysis: MW, GS, CÖ, LB. Data interpretation: MW, GS, CÖ, LB. Drafting manuscript: MW, GS, LB. Revising manuscript content: MW, GS, LB. Approving final version of manuscript: MW, GS, EFL, CÖ, TL, LB. $M W, G S$ and LB take the responsibility for the integrity of the data analysis. All authors read and approved the final manuscript.

\section{Acknowledgements}

The study was supported by Sahlgrenska University Hospital. The authors thank Cecilia Modigh for help with part of the data collection.

\section{Author details}

${ }^{1}$ Department of Occupational and Environmental Medicine, Sahlgrenska University Hospital and Academy, University of Gothenburg, PO Box 414 SE-405 30, Gothenburg, Sweden. ²Department of Nephrology, Sahlgrenska University Hospital, Gothenburg, Sweden. ${ }^{3}$ Department of Nephrology, Boras Hospital, Boras, Sweden. ${ }^{4}$ Department of Occupational and Environmental Medicine, Lund University Hospital, Lund, Sweden.

Received: 14 November 2012 Accepted: 28 February 2013 Published: 7 March 2013

\section{References}

1. EFSA: Cadmium in food - Scientific opinion of the Panel on Contaminants in the Food Chain. The EFSA Journal 2009, 980:1-139.

2. Jarup L, Berglund M, Elinder CG, Nordberg G, Vahter M: Health effects of cadmium exposure-a review of the literature and a risk estimate. Scand J Work Environ Health 1998, 24(Suppl 1):1-51.

3. Berglund M, Akesson A, Nermell B, Vahter M: Intestinal absorption of dietary cadmium in women depends on body iron stores and fiber intake. Environ Health Perspect 1994, 102:1058-1066.

4. Akesson A, Berglund M, Schutz A, Bjellerup P, Bremme K, Vahter M: Cadmium exposure in pregnancy and lactation in relation to iron status. Am J Public Health 2002, 92(2):284-287.

5. Jarup L, Akesson A: Current status of cadmium as an environmental health problem. Toxicol Appl Pharmacol 2009, 238:201-208.

6. Min K-S, Ueda H, Tanaka K: Involvement of intestinal calcium transporter 1 and metallothionein in cadmium accumulation in the liver and kidney of mice fed a low-calcium diet. Toxicol Lett 2008, 176:85-92.

7. Vesey DA: Transport pathways for cadmium in the intestine and kidney proximal tubule: Focus on the interaction with essential metals. Toxicol Lett 2010, 198:13-19.

8. Staessen JA, Roels HA, Emelianov D, Kuznetsova T, Thijs L, Vangronsveld J, Fagard R: Environmental exposure to cadmium, forearm bone density, and risk of fractures: prospective population study. Public Health and Environmental Exposure to Cadmium (PheeCad) Study Group. Lancet 1999, 353:1140-1144.

9. Alfven T, Elinder CG, Carlsson MD, Grubb A, Hellstrom L, Persson B, Pettersson C, Spang G, Schutz A, Jarup L: Low-level cadmium exposure and osteoporosis. J Bone Miner Res 2000, 15:1579-1586.

10. Alfven $T$, Elinder CG, Hellstrom L, Lagarde F, Jarup L: Cadmium exposure and distal forearm fractures. J Bone Miner Res 2004, 19:900-905.

11. Akesson A, Bjellerup P, Lundh T, Lidfeldt J, Nerbrand C, Samsioe G, Skerfving S, Vahter M: Cadmium-induced effects on bone in a population-based study of women. Environ Health Perspect 2006, 114:830-834.

12. Schutte R, Nawrot TS, Richart T, Thijs L, Vanderschueren D, Kuznetsova T, Van Hecke E, Roels HA, Staessen JA: Bone resorption and environmental exposure to cadmium in women: a population study. Environ Health Perspect 2008, 116:777-783

13. Engstrom A, Michaelsson K, Suwazono Y, Wolk A, Vahter M, Akesson A: Long-term cadmium exposure and the association with bone mineral density and fractures in a population-based study among women. $J$ Bone Miner Res 2011, 26:486-495.

14. Kazantzis G: Cadmium, osteoporosis and calcium metabolism. Biometals 2004, 17:493-498.

15. Nawrot TS, Staessen JA, Roels HA, Munters E, Cuypers A, Richart T, Ruttens A, Smeets $K$, Clijsters H, Vangronsveld J: Cadmium exposure in the 
population: from health risks to strategies of prevention. Biometals 2010, 23:769-782.

16. Potts JT: Parathyroid hormone: past and present. J Endocrinol 2005, 187:311-325.

17. Wu X, Jin T, Wang Z, Ye T, Kong Q, Nordberg G: Urinary calcium as a biomarker of renal dysfunction in a general population exposed to cadmium. J Occup Environ Med 2001, 43:898-904.

18. Kjellstrom T: Mechanism and epidemiology of bone effects of cadmium. In Cadmium in the Human Environment: Toxicity and Carcinogenicity. IARC Scientific Publication, No 118. Edited by Nordberg GF, Herber RFM, Alessio L. Lyon: IARC; 1992:301-310.

19. Buchet JP, Lauwerys R, Roels H, Bernard A, Bruaux P, Claeys F, Ducoffre G, de Plaen P, Staessen J, Amery A, Lijnen P, Thijs L, Rondia D, Sartor F, Saint Remy A, Nick L: Renal effects of cadmium body burden of the general population. Lancet 1990, 336:699-702.

20. Nawrot T, Geusens P, Nulens TS, Nemery B: Occupational cadmium exposure and calcium excretion, bone density, and osteoporosis in men. J Bone Miner Res 2010, 25:1441-1445.

21. Bernard A: Biomarkers of metal toxicity in population studies: research potential and interpretation issues. J Toxicol Environ Health A 2008, 71:1259-1265.

22. Barregard L, Fabricius-Lagging E, Lundh T, Molne J, Wallin M, Olausson M, Modigh C, Sallsten G: Cadmium, mercury, and lead in kidney cortex of living kidney donors: Impact of different exposure sources. Environ Res 2010, 110:47-54

23. Bárány E, Bergdahl I, Schütz A, Skerfving S, Oskarsson A: Inductively coupled plasma mass spectrometry for direct multi-element analysis of diluted human blood and serum. J Anal At Spectrom 1997, 12:1005-1009.

24. Shuster LT, Rhodes DJ, Gostout BS, Grossardt BR, Rocca WA: Premature menopause or early menopause: long-term health consequences. Maturitas 2010, 65:161-166.

25. Staessen J, Amery A, Bernard A, Bruaux P, Buchet JP, Claeys F, De Plaen P, Ducoffre G, Fagard R, Lauwerys RR, Lijnen P, Nick L, Saint Remy A, Roels H, Rondia D, Sartor $F$, Thijs $L$ : Effects of exposure to cadmium on calcium metabolism: a population study. Br J Ind Med 1991, 48:710-714.

26. Chaumont A, De Winter F, Dumont X, Haufroid V, Bernard A: The threshold level of urinary cadmium associated with increased urinary excretion of retinol-binding protein and beta 2-microglobulin: a re-assessment in a large cohort of nickel-cadmium battery workers. Occup Environ Med 2011, 68:257-264

27. Haddam N, Samira S, Dumont X, Taleb A, Lison D, Haufroid V, Bernard A Confounders in the assessment of the renal effects associated with lowlevel urinary cadmium: an analysis in industrial workers. Environmental health: a global access science source 2011, 10:37.

28. Nambunmee K, Honda R, Nishijo M, Swaddiwudhipong W, Nakagawa H, Ruangyuttikarn W: Bone resorption acceleration and calcium reabsorption impairment in a Thai population with high cadmium exposure. Toxicol Mech Methods 2010, 20:7-13.

29. National Institutes of Health USA: Osteoporosis prevention, diagnosis, and therapy. NIH Consens Statement 2000, 17:1-45.

doi:10.1186/1476-069X-12-22

Cite this article as: Wallin et al:: Kidney cadmium levels and associations with urinary calcium and bone mineral density: a cross-sectional study in Sweden. Environmental Health 2013 12:22.

\section{Submit your next manuscript to BioMed Central and take full advantage of:}

- Convenient online submission

- Thorough peer review

- No space constraints or color figure charges

- Immediate publication on acceptance

- Inclusion in PubMed, CAS, Scopus and Google Scholar

- Research which is freely available for redistribution

Submit your manuscript at www.biomedcentral.com/submit
C Biomed Central 